\title{
SOME ASPECTS OF STUDENTS' INTELLECTUAL SKILLS WHEN USING E-INSTRUCTIONS FOR LABORATORY PRACTICE IN ELECTRICAL TECHNOLOGY
}

\section{Stanislav VRAGAŠ - Jan KOSTELNÍK}

Resume: In our article we present selected results of a pedagogical research focused on the evaluation and comparison of electronic and traditional instruction for Laboratory Practice in Electrical Technology. The article is focused mainly on students' achievements in the final didactic test in the area of intellectual skills.

Key words: Pedagogical experiment. E-study instructions. Intellectual skills in Electrical Technology. Final didactic test.

\section{K INTELEKTOVÝM ZRUČNOSTIAM ŠTUDENTOV PRI VYUŽITÍ E-NÁVODOV NA LABORATÓRNE CVIČENIA Z ELEKTROTECHNIKY}

Resumé: Vpríspevku uvádzame vybrané výsledky pedagogického výskumu zameraného na hodnotenie a porovnanie elektronických a tradičných návodov na laboratórne cvičenia z elektrotechniky. Sústred'ujeme sa hlavne na výkony študentov vo výstupnom didaktickom teste $v$ oblasti intelektových zručností.

Kl'účové slová: Pedagogický experiment. z elektrotechniky. Výstupný didaktický test.

Úvod

V súvislosti s explóziou informácií a prechodom na informačnú spoločnost' sa stále viac zdôrazn̆uje potreba rozvoja schopností študentov získavat' informácie, orientovat' sa v explózií informácií, rozumiet' im a vediet' ich aplikovat'. Učebnice sa väčšinou tvoria dlhý čas, a preto často obsahujú už zastarané informácie. Preto je tendencia, aby čím sú študenti starší, tým viac využívali pri štúdiu primárne zdroje informácií (monografie, odborné a vedecké časopisy, zborníky $\mathrm{z}$ vedeckých konferencií a pod.). Pomocou Internetu je $\mathrm{v}$ súčasnosti možné získat' okamžite prístup do renomovaných svetových knižníc, časopisov, dennej tlače a pod. [12]

Vel'kú perspektívu pri tvorbe učebných textov majú výpočtová technika a videotechnika a ich spojenie $v$ podobe multimédií. Už v súčasnosti existujú elektronické učebnice, ktoré sú nahrané $\mathrm{v}$ podobe počítačového programu na pevnom disku, resp. nachádzajúce sa priamo na Internete. [9]

Pri tvorbe elektronických učebníc je vhodné využit' princípy programovaného vyučovania. [10] Počítač v tomto prípade môže zastúpit' učitel'a vo všetkých fázach vyučovacieho procesu. Študentov motivuje, oznámi im konkrétne (špecifické) ciele
E-študijné návody. Intelektové zručnosti vyučovania, zistí, či majú požadovanú úroveň vedomostí a zručností (pretest), vysvetlí príslušné učivo, vedie študentov pri jeho prehlbovaní a upevňovaní, vykoná kontrolu procesu učenia sa a študenta aj vyhodnotí. Umožňuje pritom individualizáciu učenia sa, a to v obsahu, metódach i čase (osobné tempo).

Realizácia výskumu: Výskum sa realizoval na Katedre fyziky UMAT MTF STU $\mathrm{v}$ Trnave $\mathrm{v}$ rámci dizertačnej práce: Tvorba, efektívnost' a kvalita hypertextových e-návodov na laboratórne cvičenia $\mathrm{z}$ elektrotechniky. Experimentálna výučba sa uskutočnila pri prvých siedmich vyučovacích jednotkách podl'a riadneho rozvrhu študentov z celkového počtu 13 vyučovacích jednotiek za semester. Empirický výskum bol dvojskupinový. V experimentálnej skupine (ES) používali študenti na prípravu na laboratórne cvičenia e-návody umiestnené na nosiči CD a v kontrolnej skupine (KS) doteraz používaný tradičný text - skriptá. Nezávislou premennou $(x)$, ktorou sa manipulovalo, boli e-učebný text. Závislými premennými (y) boli výkony študentov - ich vedomosti a intelektové zručnosti dosiahnuté vo výstupnom didaktickom teste, ich názory a postoje $\mathrm{k}$ novej forme prípravy na laboratórne cvičenia. Intervenujúce premenné boli eliminované. 
Ciele výskumu: Hlavným ciel'om výskumu bolo experimentálne overit' efektívnost' výučby laboratórnych cvičení z elektrotechniky na KF MTF STU s využitím novovytvoreného elektronického učebného textu na CD nosiči. Na splnenie tohto ciel'a boli sformulované nasledovné čiastkové ciele:

1. Vytvorit' e-učebný hypertext na laboratórne cvičenia.

2. Experimentálne overit' efektívnost' výučby $\mathrm{s}$ využitím e-návodov na laboratórne cvičenia z elektrotechniky na skupine študentov druhého ročníka MTF STU.

3. Zistit' postoje študentov $\mathrm{k}$ overovanému spôsobu výučby laboratórnych cvičení.

4. Overit' kvalitu e-návodov na laboratórne cvičenia z elektrotechniky.

5. Porovnat' novovytvorený e-učebný text a tradičný text - skriptá.

Predmet výskumu: Predmetom celého výskumu boli vedomosti a intelektové zručnosti študentov, čas na celú domácu prípravu na cvičenia, postoje študentov k experimentálnemu vyučovaniu s využitím hypertextových e-návodov na $C D$ nosiči a kvalita e-učebného textu.

Hypotézy výskumu: Vo výskume sme stanovili túto hlavnú hypotézu výskumu: Výučba laboratórnych cvičení z elektrotechniky s využitím novovytvoreného elektronického učebného textu na CD nosiči je efektívnejšia ako tradičná výučba. Aby sme mohli pravdivost' hlavnej hypotézy potvrdit', overovali sme týchto šest' pracovných hypotéz:

H1 Študenti ES dosiahnu na konci experimentálneho vyučovania lepšie vedomosti vo výstupnom DT ako študenti KS.

H2 Študenti ES dosiahnu na konci experimentálneho vyučovania lepšie intelektové zručnosti vo výstupnom DT ako študenti KS.

H3 Väčšina študentov ES sa na konci experimentu v dotazníkoch vyjadrí, že na celú domácu prípravu overovaných cvičení potrebovali rovnako alebo menej času ako študenti KS.

H4 U študentov ES budú na konci experimentu v dotazníkoch prevažovat' pozitívne hodnotenia výučby s použitím e-návodov nad negatívnymi.

H5 Kvalita e-učebného textu bude na základe expertnej metódy hodnotenia učebníc vyššia ako kvalita tradičnej učebnice - skrípt.
H6 Študenti ES budú hodnotit' kvalitu e-učebného textu prevažne pozitívnejšie ako študenti KS kvalitu tradičného textu - skrípt.

Pod hodnotením kvality e-učebného textu študentmi sme rozumeli:

1. Hodnotenie a porovnanie zrozumitel'nosti a čitatel'nosti e-učebného textu a tradičných skrípt v Cloze teste. [10]

2. Hodnotenie a porovnanie zrozumitel'nosti e-učebného textu a tradičných skrípt technikou sémantického diferenciálu. [10]

3. Odporúčanie študentov ES používat' e-učebný text aj ostatným študentom.

Použité metódy a techniky výskumu: Hlavnou metódou predloženého výskumu bol prirodzený pedagogický experiment. Ďalšie použité metódy a techniky sú nasledovné: štúdium odborných literárnych prameňov, didaktické testy, dotazníková metóda, expertná metóda, Cloze test, technika sémantického diferenciálu a štatistické metódy spracovania výsledkov výskumu. V rámci nášho výskumu sme použili jeden vstupný a jeden výstupný didaktický test. Vstupný $D T$ bol študentom zadaný za účelom rozdelenia dostupne vybraných šiestich študijných skupín na ES a KS. Po ukončení experimentu bol študentom zadaný výstupný $D T$, ktorým sa zist'ovala a porovnala úroveň vedomostí a intelektových zručností z elektrotechniky u študentov ES a KS. Tento DT bol neštandardizovaný, kognitívny, výstupný, objektívne skórovatel'ný, rozlišujúci (NR test) didaktický test. Obsahoval 20 úloh, z ktorých 5 bolo výpočtových. Úlohy výstupného DT boli vážené, skórované zložene.

\section{Výsledky verifikácie jednotlivých hypotéz:}

H1 - z výpočtu kritickej hodnoty pre dvojvýberový Wilcoxonov test homogenity vyplynul záver, že neplatí nulová hypotéza a platí alternatívna hypotéza $H 1$. Konečné rozhodnutie testovania: „Študenti ES dosiahli na konci experimentálneho vyučovania lepšie vedomosti vo výstupnom DT ako študenti KS“. H3 - z výpočtu kritickej hodnoty pre dvojvýberový Wilcoxonov test homogenity vyplynul záver, že neplatí nulová hypotéza a platí alternatívna hypotéza $H 3$. Konečné rozhodnutie testovania: „Väčšina študentov ES sa na konci experimentu $\mathrm{v}$ dotazníkoch vyjadrila, že na celú domácu prípravu overovaných cvičení potrebovala rovnako alebo menej času ako študenti KS““. 
H4 - zo získaných údajov v dotazníku sme zistili, že nejde o normálne rozloženie frekvencií (početnosti) odpovedí. Na základe tejto skutočnosti sme zvolili neparametrický $X^{2}$ - test zhody (,chí“ - kvadrát). Z výpočtu kritickej hodnoty je vidiet', že neplatí nulová hypotéza a platí alternatívna hypotéza $H 4$. Konečné rozhodnutie testovania: „U študentov ES na konci experimentu $\mathrm{v}$ dotazníkoch prevažovali pozitívne hodnotenia výučby s použitím e-návodov nad negatívnymi“.

H5 - na základe analýzy odpovedí expertov v dotazníku (ako je zrejmé i zo štatistickej deskripcie) si oprávňujeme tvrdit' nasledujúce konečné rozhodnutie: „Kvalita e-učebného textu bola na základe expertnej metódy hodnotenia učebníc vyššia ako kvalita tradičnej učebnice - skrípt".

H6 - na základe štatistickej verifikácie čiastkových hypotéz H6.1, H6.2 a H6.3 si oprávňujeme tvrdit' nasledujúce konečné rozhodnutie: „Študenti ES hodnotili kvalitu e-učebného textu prevažne pozitívnejšie ako študenti KS kvalitu tradičného textu - skrípt“".

Viac informácií a výsledky dosiahnuté $\mathrm{v}$ celom výskume sú $\mathrm{k}$ dispozícii $\mathrm{v}$ uvedenej dizertačnej práci. [17]

V príspevku z obsahových dôvodov podrobnejšie uvádzame a interpretujeme čiastkové výsledky piatich výpočtových úloh výstupného DT, zamerané na verifikáciu hypotézy $H 2$ : „Študenti ES dosiahnu na konci experimentálneho vyučovania lepšie intelektové zručnosti vo výstupnom DT ako študenti $K S$ “.

Výkony študentov MTF STU v oblasti intelektových zručností pri využití e-návodov na laboratórne cvičenia $z$ elektrotechniky

1 Výkony študentov vo výstupnom didaktickom teste v oblasti intelektových zručností

\begin{tabular}{|l|c|c|c|c|c|c|}
\hline \multirow{2}{*}{ Hodnoty skóre DT } & \multicolumn{2}{|c|}{ ES; n 29 } & \multicolumn{2}{c|}{ KS; n = 29 } & \multicolumn{2}{c|}{ ES+KS; n = 58 } \\
\cline { 2 - 7 } & {$[$ body] } & {$[\%]$} & {$[$ body] } & {$[\%]$} & {$[$ body] } & {$[\%]$} \\
\hline Aritmetický priemer $\bar{x}$ & 9,52 & 52,88 & 11,34 & 63,02 & 10,43 & 57,95 \\
\hline Medián $\tilde{x}$ & 10 & 55,60 & 13 & 72,20 & 11,5 & 63,90 \\
\hline Rozptyl $\boldsymbol{s}^{\mathbf{2}}$ & 23,08 & 711,94 & 23,47 & 724,08 & 24,11 & 743,75 \\
\hline Smerodajná odchýlka $\boldsymbol{s}$ & 4,80 & 26,68 & 4,84 & 26,91 & 4,91 & 27,27 \\
\hline Variačné rozpätie $\boldsymbol{R}$ & 16 & 88,8 & 18 & 100 & 18 & 100 \\
\hline Variačný koeficient $\boldsymbol{V}$ & - & 50,42 & - & 42,68 & - & 47,08 \\
\hline Minimum $\boldsymbol{x}_{\min }$ & 1 & 5,6 & 0 & 0,0 & 0 & 0,0 \\
\hline Maximum $\boldsymbol{x}_{\max }$ & 17 & 94,4 & 18 & 100 & 18 & 100 \\
\hline
\end{tabular}

Legenda: $n$ je počet študentov.

Tabul'ka 1: Výsledky výstupného DT v oblasti intelektových zručností (len výpočtové úlohy)

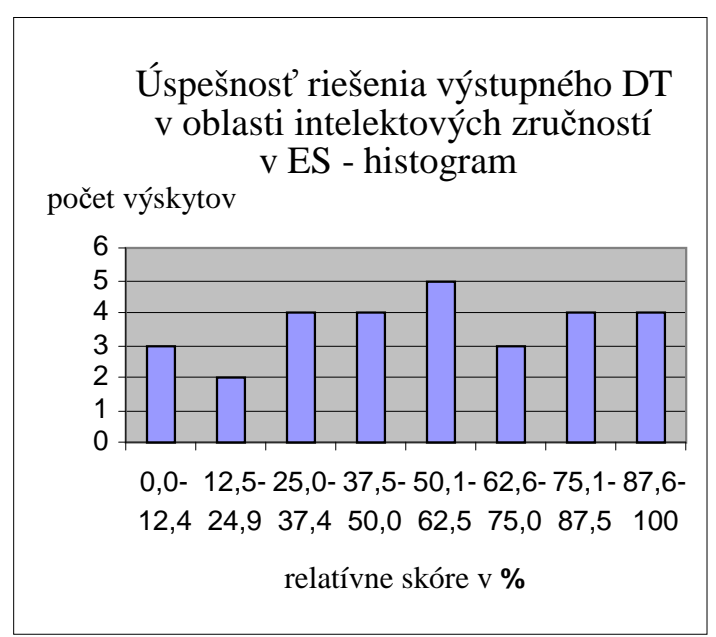

Obr. 1: Výsledky výstupného DT v ES

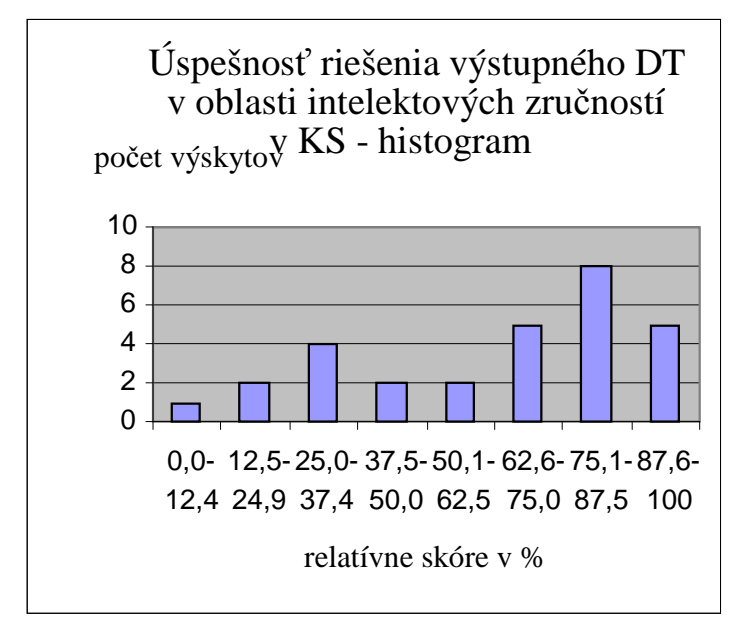

Obr. 2: Výsledky výstupného $D T$ v KS 


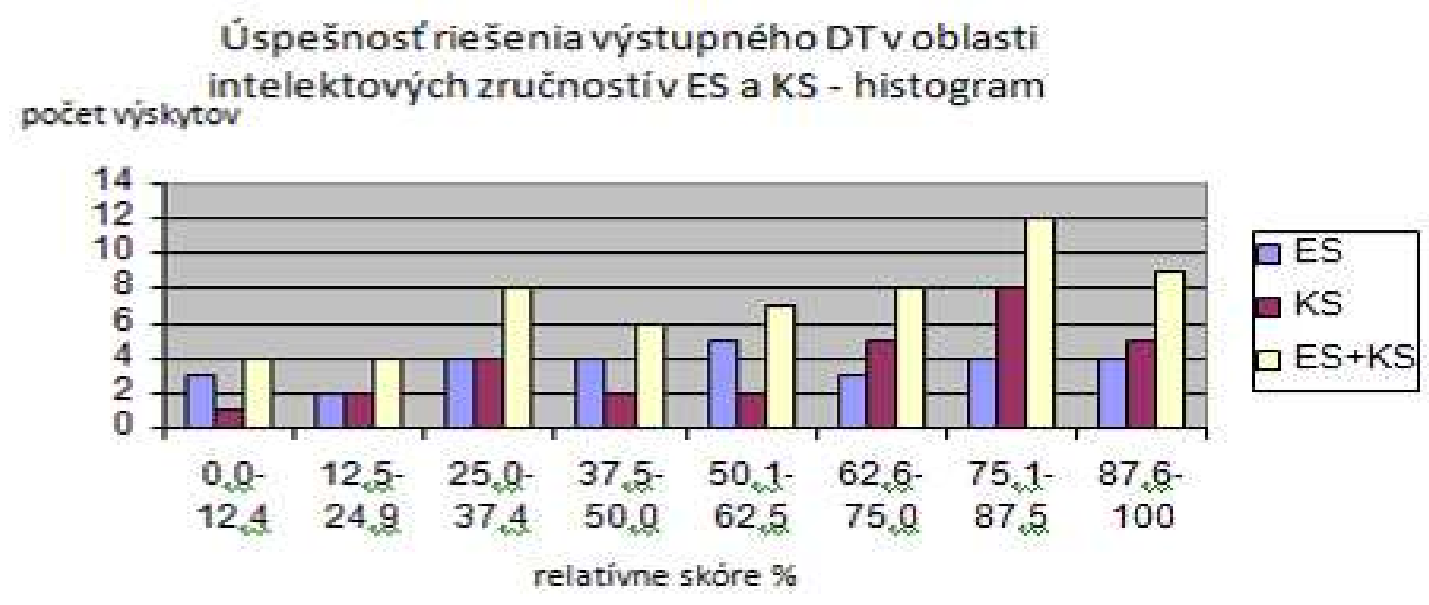

Obr. 3: Výsledky výstupného DT v ES a KS

Z kvantitatívneho spracovania výsledkov výskumu štatistickou deskripciou a ako je vidiet' $\mathrm{z}$ výsledkov v tabul'ke 1 a na obr. 1 až 3 , hypotéza $H 2$ neplatí: „Študenti $\boldsymbol{E S}$ nedosiahli na konci experimentálneho vyučovania lepšie intelektové zručnosti vo výstupnom DT ako študenti $K \boldsymbol{S}^{\text {“. }}$ Z $\mathrm{Z}$ tabul'ky 1 d'alej vidíme, že variačný koeficient $V \mathrm{v}$ ES prekročil hodnotu $50 \%(V=50,42 \%)$, tzn., že táto skupina je tak nesúrodá (heterogénna), že aritmetický priemer tu stráca význam a nemôže ju reprezentovat' a namiesto neho sme používali vo všetkých vzt'ahoch medián [8]. Stredná hodnota skóre DT v oblasti intelektových zručností v ES $(55,60 \%)$ bola nižšia ako stredná hodnota v KS $(63,02 \%)$.

Aj pri kvantitatívnom vyhodnotení výsledkov štatistickou indukciou (verifikáciou výskumnej hypotézy $H 2$ ) sa nám potvrdilo jej zamietnutie. Najskôr sme testom normality (Shapiroov - Wilkov test) [3] zistili, či skúmané výbery vES aj KS majú normálne rozdelenie pravdepodobnosti alebo nie. Výber v ES má normálne rozdelenie a výber KS nie je normálne rozdelený. Pre kvantitatívny znak skóre výstupného DT v oblasti intelektových zručností sme preto zvolili neparametrický test zhody (Wilcoxonov test homogenity) [3]. $Z$ tohto testu hypotézy o rovnosti dvoch distribučných funkcií vyplynul záver, že platí nulová hypotéza $\left(H_{0}\right.$ : obidva výbery ES aj KS pochádzajú $\mathrm{z}$ toho istého rozdelenia pravdepodobnosti) a neplatí alternatívna hypotéza $H 2$.

Po následnej analýze a rozbore, prečo sa hypotéza $H 2$ nepotvrdila, zistili sme tesnost' vzt’ahu - koreláciu medzi ukončenou strednou školou a intelektovými zručnost’ami u študentov KS, ktorý uvádzame v d’alšej časti článku.

\section{Korelácia medzi ukončenou strednou školou a intelektovými zručnost’ami študentov kontrolnej skupiny}

Tesnost' vzt'ahu medzi absolvovanou strednou školou a intelektovými zručnost'ami u študentov KS sme kvantifikovali pomocou Spearmanovho korelačného koeficientu $R$. [7] Na hladine významnosti $\alpha=0,05$ sme zistili, že tento koeficient je štatisticky významný a platí aj na základný súbor. Nám vyšla vysoká hodnota koeficientu korelácie $R=0,76$, preto sme odmietli nulovú hypotézu o nezávislosti sledovaných súborov, tzn. že medzi porovnávanými súbormi (premennými) existuje štatisticky významná závislost'. Kladná hodnota koeficientu korelácie $R$ znamená, že s rastúcimi hodnotami $x_{\mathrm{i}}$ rastú aj hodnoty $y_{\mathrm{i}}$, tzn., že čím viac študentov bude absolventmi strednej školy so zameraním elektro alebo technickým, tým viac možno očakávat', že budú mat' aj lepšie intelektové zručnosti z elektrotechniky.

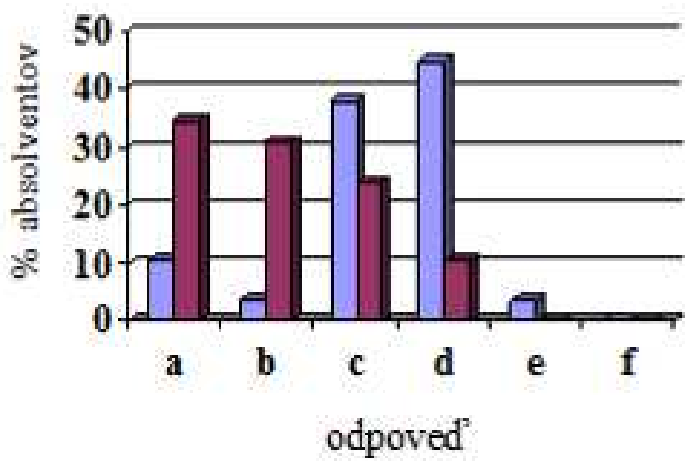

口ES

$\square \mathrm{KS}$

Obr. 4: Ukončená stredná škola 
Na obr. 4 je uvedená ukončená stredná škola študentov, kde:

a) SPŠ, resp. SOU elektro zamerania

b) SPŠ, resp. SOU technického zamerania, okrem elektro

c) Gymnázium

d) OA, SPŠ, resp. SOU ekonomického zamerania (TAP, TIS, ...)

e) SPŠ, resp. SOU umeleckého zamerania

f) SŠ iného zamerania
Záver

Predložený pedagogický výskum experimentálne overil efektívnost' vyučovania laboratórnych cvičení z elektrotechniky na MTF STU v Trnave s využitím e-návodov. Metódy získavania faktov a platnost' pracovných hypotéz je zhrnutá v nasledujúcej tabul'ke 2.

\begin{tabular}{|c|c|c|c|}
\hline Hypotéza & Metóda získavania faktov & Platnost' hypotézy & Skúmaná veličina \\
\hline$H 1$ & didaktický test & sa potvrdila & vedomosti \\
\hline $\mathrm{H} 2$ & didaktický test & sa nepotvrdila & intelektové zručnosti \\
\hline $\boldsymbol{H 3}$ & dotazník & sa potvrdila & čas na domácu prípravu \\
\hline $\mathrm{H4}$ & dotazník & sa potvrdila & $\begin{array}{l}\text { názory a postoje } \\
\text { študentov k novému } \\
\text { spôsobu výučby }\end{array}$ \\
\hline H5 & $\begin{array}{l}\text { expertná metóda, technika } \\
\text { sémantického diferenciálu, } \\
\text { dotazník }\end{array}$ & sa potvrdila & $\begin{array}{l}\text { kvalita e-návodov; } \\
\text { názory, postoje a } \\
\text { hodnotenie expertov }\end{array}$ \\
\hline H6 & $\begin{array}{l}\text { Cloze test, technika } \\
\text { sémantického diferenciálu, } \\
\text { dotazník }\end{array}$ & sa potvrdila & $\begin{array}{l}\text { kvalita e-návodov; } \\
\text { názory, postoje } \\
\text { a hodnotenie študentov }\end{array}$ \\
\hline
\end{tabular}

Tabul'ka 2: Sumarizácia verifikácie hypotéz

Príčiny skutočnosti, že študenti ES nedosiahli lepšie priemerné výsledky v oblasti intelektových zručností mohli byt' viaceré:

- Krátka doba experimentu (za sedem vyučovacích jednotiek nemožno očakávat' signifikantné zmeny $\mathrm{v}$ intelektových zručnostiach študentov - riešení výpočtových úloh z elektrotechniky).

- V KS bola väčšina študentov, ktorá absolvovala strednú školu s elektro alebo technickým zameraním $(65,5 \%)$, zatial' čo väčšina študentov v ES boli absolventmi strednej školy s ekonomickým zameraním alebo gymnázií (82,7 \%), ktorí predmet elektrotechnika nemali zaradený $\mathrm{v}$ učebných osnovách.

- V neposlednom rade výsledky vo vel'kej miere ovplyvnil osobný záujem a samotný prístup k vyučovaniu zo strany študenta.

Napriek tomu, že študenti experimentálnej skupiny nedosiahli lepšie intelektové zručnosti vo výstupnom didaktickom teste, celkové výsledky výskumu potvrdili, že výučba pomocou e-návodov [17]:
- zvyšuje výkon študentov v kognitívnej oblasti

- usmern̆uje (riadi) domácu prípravu študentov na cvičenia,

- zefektívňuje domácu prípravu študentov na cvičenia (skracuje čas prípravy a študenti nemusia používat' viaceré zdroje literatúry),

- motivuje študentov,

- zvyšuje atraktivitu štúdia,

- vedie študentov k väčšej samostatnosti počas ich štúdia,

- rozvíja spôsobilosti študentov pre prácu s PC.

Aj názory a postoje expertov a študentov nasvedčujú, že e-návody sú lepšie ako klasický text - skriptá a odporúčajú ich doplnit' o ostatné vyučovacie jednotky a ich disemináciu medzi študentov.

Hlavný prínos práce vidíme vo vytvorení eučebného textu, ktorý bol pozitívne prijatý a sprístupnenie úplnej verzie e-návodov v AIS STU. 
Literatúra

(1) KOSORIN, D.- RIEDLMAJER, R.JANČUŠKA, I. Elektrotechnika. Návody na laboratórne cvičenia. 1. vyd. Bratislava: STU, 2002. 203 s. ISBN 80-227-1717-7

(2) KOSTELNÍK, J. Riadenie samostatnej práce študentov stredných a vysokých škôl. 1. vyd. Bratislava: STU, 1998. 58 s. ISBN 80-2271043-1

(3) KUBÁČKOVÁ, L. Metódy spracovania experimentálnych údajov. Bratislava: VEDA, 1990. 328 s. ISBN 80-224-0104-8

(4) PRŮCHA, J. Moderní pedagogika. 2. přeprac. a aktualiz. vyd. Praha: Portál, 2002. 481 s. ISBN 80-7178-631-4

(5) PRŮCHA, J.- WALTEROVÁ, E.MAREŠ, J. Pedagogický slovník. 3. rozš. a aktualiz. vyd. Praha: Portál, 2001.328 s. ISBN 80-7178-579-2

(6) PRŮCHA, J. Pedagogický výzkum: uvedení do teorie a praxe. 1. vyd. Praha: Karolinum, 1995. ISBN 80-7184-132-3

(7) REISENAUER, R. Metody matematické statistiky a jejich aplikace v technice. 2. rev. a dopl. vyd. Praha: SNTL, 1970. 240 s.

(8) TINÁKOVÁ, K.- TUREK, I. Skúšanie a hodnotenie žiakov. Online učebný text pre DPŠ učitel'ov technických odborných predmetov na stredných školách, absolventov univerzít technického zamerania. Bratislava: STU, 2004. ISBN 80-227-2068-2 (CD ROM)

(9) TUREK, I. Inovácie v didaktike. Bratislava: M-PC, 2004. 364 s. ISBN 80-8052-188-3

(10) TUREK, I. Tvorba zrozumitel'ného textu. Experimentálny učebný text. Bratislava: STU, 1997. 46 s. ISBN 80-967249-9-1

(11) TUREK, I. Základy pedagogického výskuтu. 1. vyd. Prešov. KPÚ, 2002. (sprístupnené autorom na diskete)

(12) VRAGAŠ, S.- KOSTELNÍK, J. Evaluácia kvality e-učebného hypertextu z elektrotechniky expertnou metódou. In: Časopis Vedecké práce Materiálovotechnologickej fakulty STU. Trnava: AlumniPress, 2007, číslo 23. ISSN 1336-1589

(13) VRAGAŠ, S. - KOSTELNÍK, J. Porovnanie kvality hypertextových e-návodov a tradičných návodov na laboratórne cvičenia z elektrotechniky. In: SCHOLA 2007. Trnava: STU, 2007. ISBN 978-80-8096-038-4. (CD ROM)

(14) VRAGAŠ, S.- KOSTELNÍK, J. Použitie hypertextových e-návodov vo vyučovaní elektrotechniky na MTF STU. In: SCHOLA 2006. Bratislava: STU, 2006. s. 450 - 454. ISBN 80-227-2389-4

(15) VRAGAŠ, S.- KOSTELNÍK, J. Využívanie e-textov $\mathrm{k}$ domácej príprave študentov na laboratórne cvičenia z elektrotechniky. In: Internetový časopis MTF STU v Trnave. 8. ročník 2008 - číslo 6. ISSN 1335-9053. Dostupné na internete: http://www.mtf.stuba.sk/docs// internetovy_casopis/2008/obsah.htm .

(16) RAGAŠ, S. Hodnotenie výučby s využitím hypertextových e-návodov z elektrotechniky študujúcimi. In: Internetový časopis MTF STU v Trnave. ročník - 2007 - číslo 3. ISSN 1335-9053. Dostupné na internete: http://www.mtf.stuba.sk/docs//internetovy_caso pis/2007/3/obsah.htm .

(17) VRAGAŠ, S. Tvorba, efektívnost' a kvalita hypertextových e-návodov na laboratórne cvičenia zelektrotechniky. Dizertačná práca. Trnava: KIPP UIPH MTF STU, 2007.

Ing. Stanislav Vragaš, PhD.

doc. PhDr. Ing. Jan Kostelník, PhD.*

Katedra fyziky UMAT MTF STU

Katedra inžinierskej pedagogiky a psychológie UIPH MTF STU*

J. Bottu 25, 91724 Trnava

Paulínska 16, 91724 Trnava*

Tel.: + 421-33/5521 002, kl. 91

+ 421-33/5511 032, kl. 136;

$+421-918 / 646027^{*}$

E-mail: stanislav.vragas@stuba.sk

jan.kostelnik@stuba.sk

www: http://www.mtf.stuba.sk/ 